\title{
Correction to: Sample-based longitudinal discrete choice experiments: preferences for electric vehicles over time
}

\author{
Katharina Keller $^{1}$ (D) Christian Schlereth $^{2} \cdot$ Oliver Hinz $^{1}$
}

Published online: 13 April 2021

(C) Academy of Marketing Science 2021

\section{Correction to: Journal of the Academy of Marketing Science.} https://doi.org/10.1007/s11747-020-00758-8

The original version of this article unfortunately contained mistakes in Eq. 5 which were introduced during the production process. "array*20c" and ",array" were added in the equation. Please see below correct equation:

$$
\begin{aligned}
v_{i, t} & =\left(\alpha_{0, t 1}+w \cdot \Delta \alpha_{0}\right)+\left(\alpha_{1, t 1}+w \cdot \Delta \alpha_{1}\right) \cdot x_{i, 1}+\left(\alpha_{2, t 1}\right. \\
& \left.+w \cdot \Delta \alpha_{2}\right) \cdot\left(x_{i, 2, t 1}+w \cdot \Delta x_{2}\right) \quad\left(i \in I_{a} ; t \in\{t 1, t 2\}\right) .
\end{aligned}
$$

The original article has been corrected.

Publisher's note Springer Nature remains neutral with regard to jurisdictional claims in published maps and institutional affiliations.

The online version of the original article can be found at https://doi.org/ $10.1007 / \mathrm{s} 11747-020-00758-8$

\footnotetext{
Katharina Keller

kakeller@wiwi.uni-frankfurt.de

Christian Schlereth

christian.schlereth@whu.edu

Oliver Hinz

ohinz@wiwi.unifrankfurt.de

1 Goethe University Frankfurt, Theodor-W.-Adorno Platz 4, 60323 Frankfurt am Main, Germany

2 WHU - Otto Beisheim School of Management, Burgplatz 2, 56179 Vallendar, Germany
} 